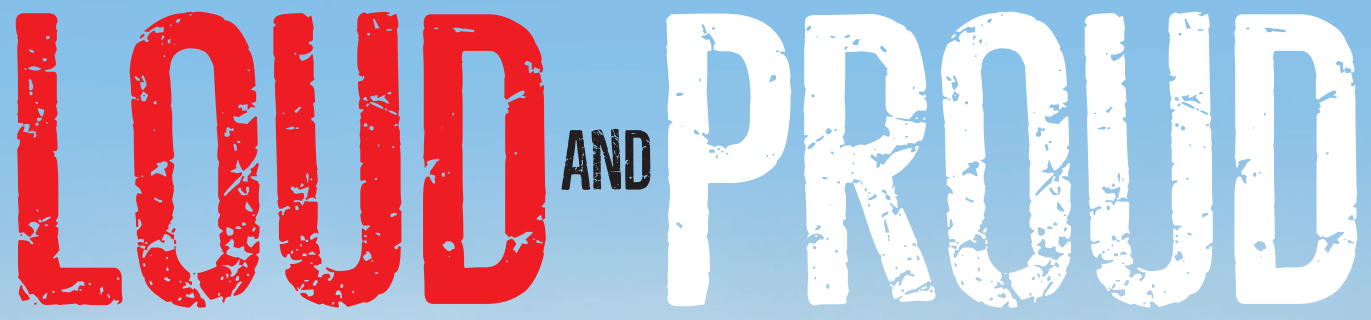

\title{
PASSION AND POLITICS IN THE ENGLISH DEFENCE LEAGUE
}
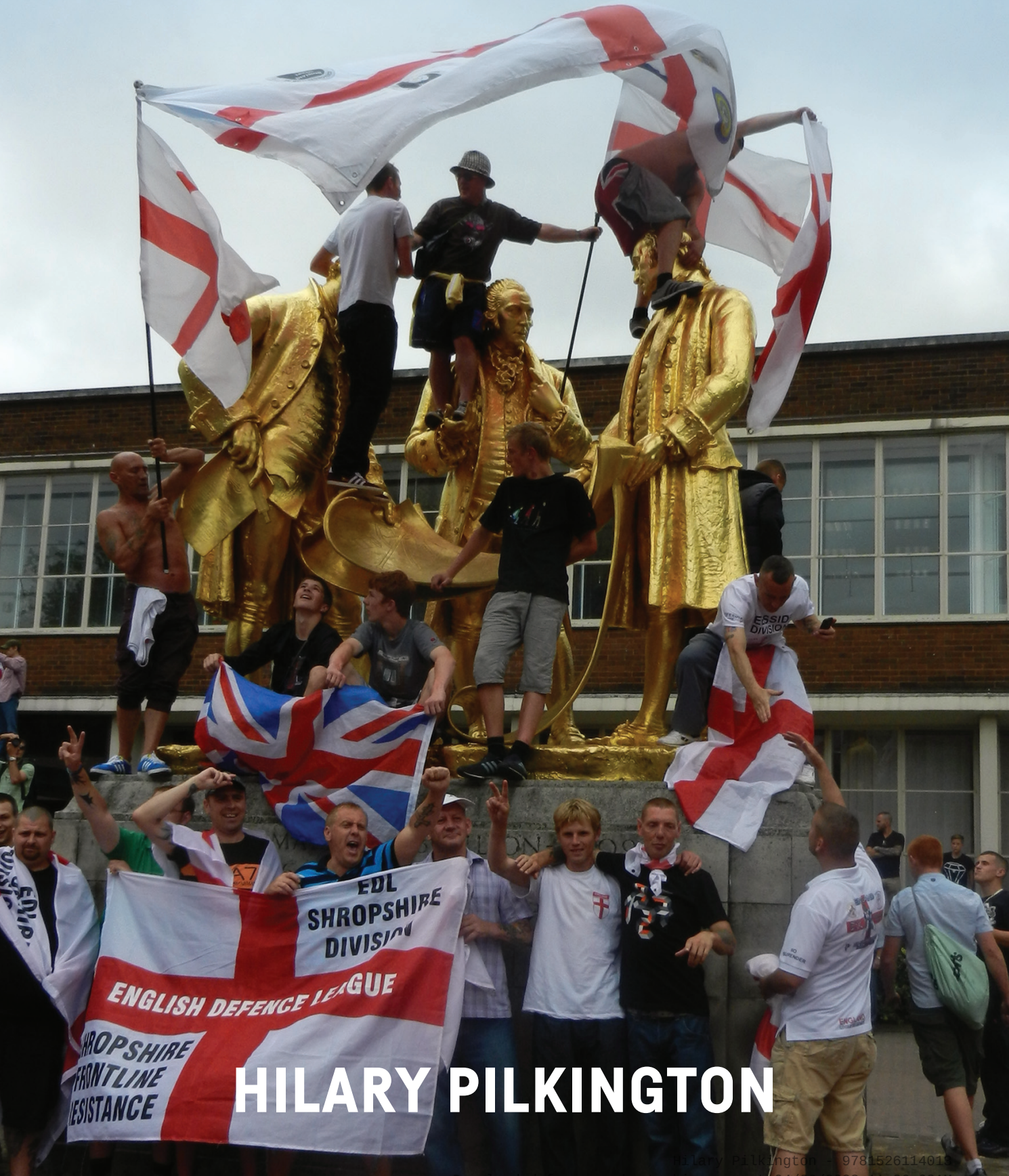


\section{Loud and proud}

\section{MANCHESTER}

1824

Manchester University Press 


\section{Ethnographies}

Series editor

Alexander Thomas T. Smith

\section{Already published}

The British in rural France:

Lifestyle migration and the ongoing quest for a better way of life Michaela Benson

Ageing selves and everyday life in the North of England: Years in the making Catherine Degnen

Chagos islanders in Mauritius and the UK:

Forced displacement and onward migration Laura Jeffery

South Korean civil movement organisations: Hope, crisis and pragmatism in democratic transition

Amy Levine

Integration in Ireland: The everyday lives of African migrants

Fiona Murphy and Mark Maguire

An ethnography of English football fans: Cans, cops and carnivals

Geoff Pearson

Iraqi women in Denmark: Ritual performance and belonging in everyday life

Marianne Holm Pedersen

Literature and agency in English fiction reading:

A study of the Henry Williamson Society

Adam Reed

International seafarers and transnationalism in the twenty-first century

Helen Sampson

Devolution and the Scottish Conservatives:

Banal activism, electioneering and the politics of irrelevance

Alexander Smith

Exoticisation undressed: Ethnographic nostalgia and authenticity in

Emberá clothes

Dimitrios Theodossopoulos

Immersion: Marathon swimming, embodiment and identity

Karen Throsby

Enduring violence: Everyday life and conflict in eastern Sri Lanka

Rebecca Walker

Performing Englishness: Identity and politics in a contemporary folk resurgence

Trish Winter and Simon Keegan-Phipps 


\title{
Loud and proud \\ Passion and politics in the English Defence League
}

\author{
Hilary Pilkington
}

Manchester University Press 
Copyright @ Hilary Pilkington 2016

The right of Hilary Pilkington to be identified as the author of this work has been asserted by her in accordance with the Copyright, Designs and Patents Act 1988.

Published by Manchester University Press

Altrincham Street, Manchester M1 7JA

www.manchesteruniversitypress.co.uk

British Library Cataloguing-in-Publication Data

A catalogue record for this book is available from the British Library

Library of Congress Cataloging-in-Publication Data applied for

An electronic version of this book is also available under a Creative Commons

(CC-BY-NC) Licence.

$\begin{array}{lll}\text { ISBN } & 9781526114013 & \text { open access } \\ \text { ISBN } & 9781784992590 & \text { paperback }\end{array}$

First published 2016

The publisher has no responsibility for the persistence or accuracy of URLs for any external or third-party internet websites referred to in this book, and does not guarantee that any content on such websites is, or will remain, accurate or appropriate.

Typeset in Minion by

Servis Filmsetting Ltd, Stockport, Cheshire 